\title{
Regulation and Immunohistochemical Localization of $\beta \gamma$-Stimulated Adenylyl Cyclases in Mouse Hippocampus
}

\author{
Lauren P. Baker, Mark D. Nielsen, Soren Impey, Beth M. Hacker, Steven W. Poser, Mandy Y. M. Chan, and \\ Daniel R. Storm
}

Department of Pharmacology, University of Washington, Seattle, Washington 98195-7280

\begin{abstract}
Specific forms of synaptic plasticity such as long-term potentiation (LTP) are modulated by or require increases in cAMP. The various adenylyl cyclase isoforms possess unique regulatory properties, and thus CAMP increases in a given cell type or tissue in response to converging signals are subject to the properties of the adenylyl cyclase isoforms expressed. In most tissues, adenylyl cyclase activity is stimulated by neurotransmitters or hormones via stimulatory $G$-protein $\left(G_{s}\right)$-coupled receptors and is inhibited via inhibitory $G$-protein $\left(G_{i}\right)$-linked receptors. However, in the hippocampus, stimulation of $\mathrm{G}_{\mathrm{i}}{ }^{-}$ coupled receptors potentiates $\mathrm{G}_{\mathrm{s}}$-stimulated cAMP levels. This effect may be associated with the regulatory properties of adenylyl cyclase types 2 and 4 (AC2 and AC4), isoforms that are potentiated by the $\beta \gamma$ subunit of $\mathrm{G}_{\mathrm{i}}$ in vitro. Although AC2 has been shown to be stimulated by $\beta \gamma$ in whole cells, reports
\end{abstract}

describing the sensitivity of AC4 to $\beta \gamma$ in vivo have yet to emerge. Our results demonstrate that $\mathrm{G}_{\mathrm{s}}$-mediated stimulation of AC4 is potentiated by $\beta \gamma$ released from activated $\mathrm{G}_{\mathrm{i}}$-coupled receptors in intact human embryonic kidney (HEK) 293 cells. Furthermore, we show that the AC2 and AC4 proteins are expressed in the mouse hippocampal formation and that they colocalize with MAP2, a dendritic and/or postsynaptic marker. The presence of AC2 and AC4 in the hippocampus and the ability of each of these enzymes to detect coincident activation of $G_{s}$-and $G_{i}$-coupled receptors suggest that they may play a crucial role in certain forms of synaptic plasticity by coordinating such overlapping synaptic inputs.

Key words: adenylyl cyclase; cAMP; G-protein; $\beta \gamma$; hippocampus; synaptic plasticity; immunohistochemistry; immunocytochemistry
The regulation of adenylyl cyclases by G-protein-coupled receptors is a classically described mechanism in which a stimulatory G-protein $\left(G_{s}\right)$ couples neurotransmitters to activation of adenylyl cyclase, whereas an inhibitory G-protein $\left(G_{i}\right)$ couples to inhibition of adenylyl cyclase. In certain tissues, $G_{i}$ signaling can potentiate $\mathrm{G}_{\mathrm{s}}$ input (Andrade, 1993; Gereau and Conn, 1994; Pian and Dobbs, 1995; Olianas et al., 1998). Specifically, norepinephrine- or isoproterenol-induced increases in cAMP are enhanced by activation of $\mathrm{G}_{\mathrm{i}}$-coupled $5-\mathrm{HT}_{1 \mathrm{~A}}$ or $\mathrm{GABA}_{\mathrm{B}}$ receptors (Andrade, 1993).

Although the $\mathrm{Ca}^{2+}$-stimulated adenylyl cyclases (AC1 and AC8) are believed to play a role in synaptic plasticity in the hippocampus (Choi et al., 1993; Weisskopf et al., 1994; Wu et al., 1995; Xia et al., 1995; Villacres et al., 1998), other isoforms may also be necessary. For example, at the mossy fiber (mf)-CA3 synapse, long-term potentiation (LTP) is dependent on opioid neurotransmission (Williams and Johnston, 1996). Opioid receptors are coupled to $\mathrm{G}_{\mathrm{i}} / \mathrm{G}_{\mathrm{o}}$, and pertussis toxin treatment prevents the development of LTP at this synapse (Ito et al., 1988). In addition, elevation of cAMP is required for mf-CA3 LTP

\footnotetext{
Received July 22, 1998; revised Sept. 28, 1998; accepted Oct. 15, 1998.

This work was supported by National Institutes of Health Grant 20498 to D.R.S. We thank Drs. Karl Obrietan for providing thick tissue sections, Jean-Christophe Deloulme for aid with Western blot analysis, and Ruth Westenbroek for valuable discussions regarding the immunohistochemistry. We thank Lisa Prichard, Scott Wong, Kien Trinh, Jaime Athos, Bill Watt, and Drs. Guy Chan, Ulrika Lernmark, and Karl Obrietan for critical reading of this manuscript. Confocal imaging and analysis were performed at the William M. Keck Imaging Center (University of Washington, Seattle, WA).

Correspondence should be addressed to Dr. Daniel R. Storm, Department of Pharmacology, Box 357280, University of Washington, Seattle, WA 98195-7280.

Drs. Baker and Nielsen are coprimary authors.

Copyright (C) 1998 Society for Neuroscience $\quad 0270-6474 / 98 / 190180-13 \$ 05.00 / 0$
}

(Huang et al., 1994, 1995; Weisskopf et al., 1994) as well as for long-lasting LTP in area CA1 (Frey et al., 1993). Pertussis toxin treatment has also been demonstrated to prevent the formation of LTP in area CA1 (Goh and Pennefather, 1989, 1990).

To date, nine mammalian adenylyl cyclase isotypes (AC1AC9) have been identified (Krupinski et al., 1989; Bakalyar and Reed, 1990; Feinstein et al., 1991; Gao and Gilman, 1991; Ishikawa et al., 1992; Katsushika et al., 1992; Premont et al., 1992, 1996; Yoshimura and Cooper, 1992; Cali et al., 1994; Hellevuo et al., 1995). Each is distributed and regulated uniquely (Choi et al., 1993; Iyengar, 1993; Cooper et al., 1995; Taussig and Gilman, 1995; Xia et al., 1995; Sunahara et al., 1996). mRNA has been detected for AC1 (Xia et al., 1991), AC2 (Furuyama et al., 1993), AC3 (Glatt and Snyder, 1993), AC8 (Cali et al., 1994), and AC9 (Premont et al., 1996) in the mammalian hippocampus.

The in vitro regulatory properties of AC2 and AC4 are consistent with the possibility of a role in $\mathrm{G}_{\mathrm{i}}$-mediated potentiation of $\mathrm{G}_{\mathrm{s}}$-stimulated cAMP. The activity of both isoforms is potentiated in vitro by $\mathrm{G}_{\mathrm{i}}$ in the presence of $\mathrm{G}_{\mathrm{s}}$ (Feinstein et al., 1991; Gao and Gilman, 1991; Lustig et al., 1993). Whereas AC2 has been characterized extensively in intact cells (Federman et al., 1992; Jacobowitz et al., 1993; Lustig et al., 1993; Tsu and Wong, 1996), in vivo regulatory properties of AC4 have not been defined. Furthermore, it is not known whether either of the $\beta \gamma$-stimulated adenylyl cyclase proteins is expressed in the hippocampus. To assess whether AC2 and/or AC4 could be involved in the control of hippocampal cAMP levels, we determined the immunohistochemical localization of AC2 and AC4 proteins in the mouse hippocampus and characterized the regulation of AC4 in human embryonic kidney (HEK) 293 cells. Our findings suggest that the presence of $\mathrm{AC} 2$ and/or AC4 in the hippocampus may account for 
some of the electrophysiological and biochemical effects of coincident $\mathrm{G}_{\mathrm{s}}$ - and $\mathrm{G}_{\mathrm{i}}$-coupled receptor activation (Andrade, 1993; Gereau and Conn, 1994).

\section{MATERIALS AND METHODS}

Materials. Isoproterenol, 3-methyl-1-isobutylxanthine (IBMX), serotonin, and somatostatin-14 were purchased from Sigma (St. Louis, MO). Pertussis toxin was obtained from List Biologic (Campbell, CA). Restriction endonucleases and DNA ligase were purchased from New England Biolabs (Beverly, MA). Polyclonal antibodies generated against adenylyl cyclases 2 or 4 were generously provided by Santa Cruz Biotechnology (Santa Cruz, CA). Monoclonal antibodies generated against MAP-2 or synaptophysin were purchased from Sigma.

Cell culture. HEK 293 cells were grown at $37^{\circ} \mathrm{C}$ in HEPES-buffered (H)-DMEM supplemented with $10 \%$ bovine calf serum (BCS) and $1 \%$ penicillin and streptomycin in a humidified $95 \% \mathrm{O}_{2} / 5 \% \mathrm{CO}_{2}$ incubator. Cell culture materials were obtained from Life Technologies (Gaithersburg, MD) unless otherwise indicated.

Expression of the 5-HT $7 A$ receptor and AC2 or AC4 in HEK 293 cells. The AC4 cDNA clone was generously provided by Drs. Wei-Jen Tang and Alfred G. Gilman (University of Texas Southwestern Medical Center, Dallas, TX). The AC4 insert was released from pBluescript (Stratagene, La Jolla, CA) by digestion with KpnI and BamHI and was ligated into the pCEP4 expression vector (Invitrogen, San Diego, CA). The AC2 cDNA was generously provided by Dr. Randall R. Reed (Johns Hopkins School of Medicine, Baltimore, MD) and was ligated into pCEP4. The $5-\mathrm{HT}_{7 \mathrm{~A}}$ receptor cDNA clone was a gift from Dr. Mark Hamblin (Veterans Administration Medical Center, Seattle, WA) and was ligated into pcDNAIII (Invitrogen). Polyclonal populations of G418- $(500 \mu \mathrm{g} / \mathrm{ml}$; Calbiochem, La Jolla, CA) and/or hygromycin- (400 $\mu \mathrm{g} / \mathrm{ml}$; Calbiochem) resistant 293 cells were obtained by stable transfection of the pcDNAIII or pCEP4 expression vector and/or pcDNAIII-5-HT ${ }_{7 \mathrm{~A}}$ or pCEP4-AC4 (or pCEP4-AC2 alone for analysis of AC2 expression by immunocytochemistry) using the calcium phosphate method (Chen and Okayama, 1987). All stable cell lines were created from the same parental population of HEK 293 cells. Expression of 5- $\mathrm{HT}_{7 \mathrm{~A}}$ or exogenous adenylyl cyclases was determined by cAMP accumulation assays as described below.

cAMP accumulation assay. Changes in intracellular cAMP were measured by determining the ratio of $\left[{ }^{3} \mathrm{H}\right] \mathrm{cAMP}$ to the total ATP, ADP, and AMP pool in $\left[{ }^{3} \mathrm{H}\right]$ adenine-loaded cells as described previously (Wong et al., 1991). This assay system allows for rapid and sensitive determination of relative changes in intracellular CAMP. Although the ratios measured between assays generally vary somewhat, the relative change in cAMP observed between assays is very reproducible. In brief, as cells in 12-well plates approached confluency, they were incubated in H-DMEM plus $10 \%$ BCS containing $2 \mu \mathrm{Ci}$ of $\left[{ }^{3} \mathrm{H}\right]$ adenine (ICN Biochemicals, Costa Mesa, CA) per well for 16-20 hr. The next day, the labeling medium was aspirated, and the cells were washed once with $150 \mathrm{~mm} \mathrm{NaCl}$ and incubated in H-DMEM plus $1 \%$ penicillin and streptomycin containing the indicated effectors (e.g., isoproterenol, serotonin, and somatostatin) plus $1 \mathrm{mM}$ IBMX for $30 \mathrm{~min}$. Reactions were terminated by aspiration of the medium and addition of $1 \mathrm{ml}$ of ice-cold $5 \%$ trichloroacetic acid plus $1 \mu \mathrm{M}$ cAMP. Culture dishes were maintained at $4^{\circ} \mathrm{C}$ for $1-4 \mathrm{hr}$, and acid-soluble nucleotides were separated by sequential Dowex AG50WX-4 and neutral alumina chromatography as described previously (Salomon et al., 1974). The data are reported as the average of triplicate determinations. Pertussis toxin, when used, was added to cells during the $\left[{ }^{3} \mathrm{H}\right]$ adenine-labeling period for $16-20 \mathrm{hr}$.

Transient coexpression of AC4 with the $C$ terminal of $\beta$-adrenergic receptor kinase 1 or transducin $\alpha$ in HEK 293 cells. The peptide minigene construct encoding the $\mathrm{C}$ terminal of $\beta$-adrenergic receptor kinase 1

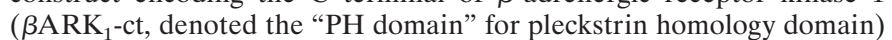
in the pRK5 plasmid (Koch et al., 1994) was generously provided by Dr. Robert Lefkowitz (Duke University Medical Center, Durham, NC). A cDNA clone for the $\alpha$ subunit of human rod transducin (denoted $G_{t}$ ) was provided by Dr. Neil M. Nathanson (University of Washington, Seattle, WA). Briefly, the night before transfection, cells were plated onto 100 $\mathrm{mm}$ plates at a density of $\sim 70 \%$. The following morning, each plate was transfected with $8 \mu \mathrm{g}$ of total DNA [ $1 \mu \mathrm{g}$ of $5-\mathrm{HT}_{7 \mathrm{~A}}, 2.5 \mu \mathrm{g}$ of pCEP4 or pCEP4-AC4, $4 \mu \mathrm{g}$ of pCDNAIII, pCDNAIII-transducin $\alpha$, or pRK$\beta \mathrm{ARK}_{1}$-ct, and $0.5 \mu \mathrm{g}$ of Rous sarcoma virus (RSV)- $\beta$-galactosidase] in $\mathrm{H}-\mathrm{DMEM}$ in the presence of 50-60 $\mu \mathrm{l}$ of Lipofectamine (Life Technologies). After $5 \mathrm{hr}$, cells were rinsed with H-DMEM plus $1 \%$ penicillin
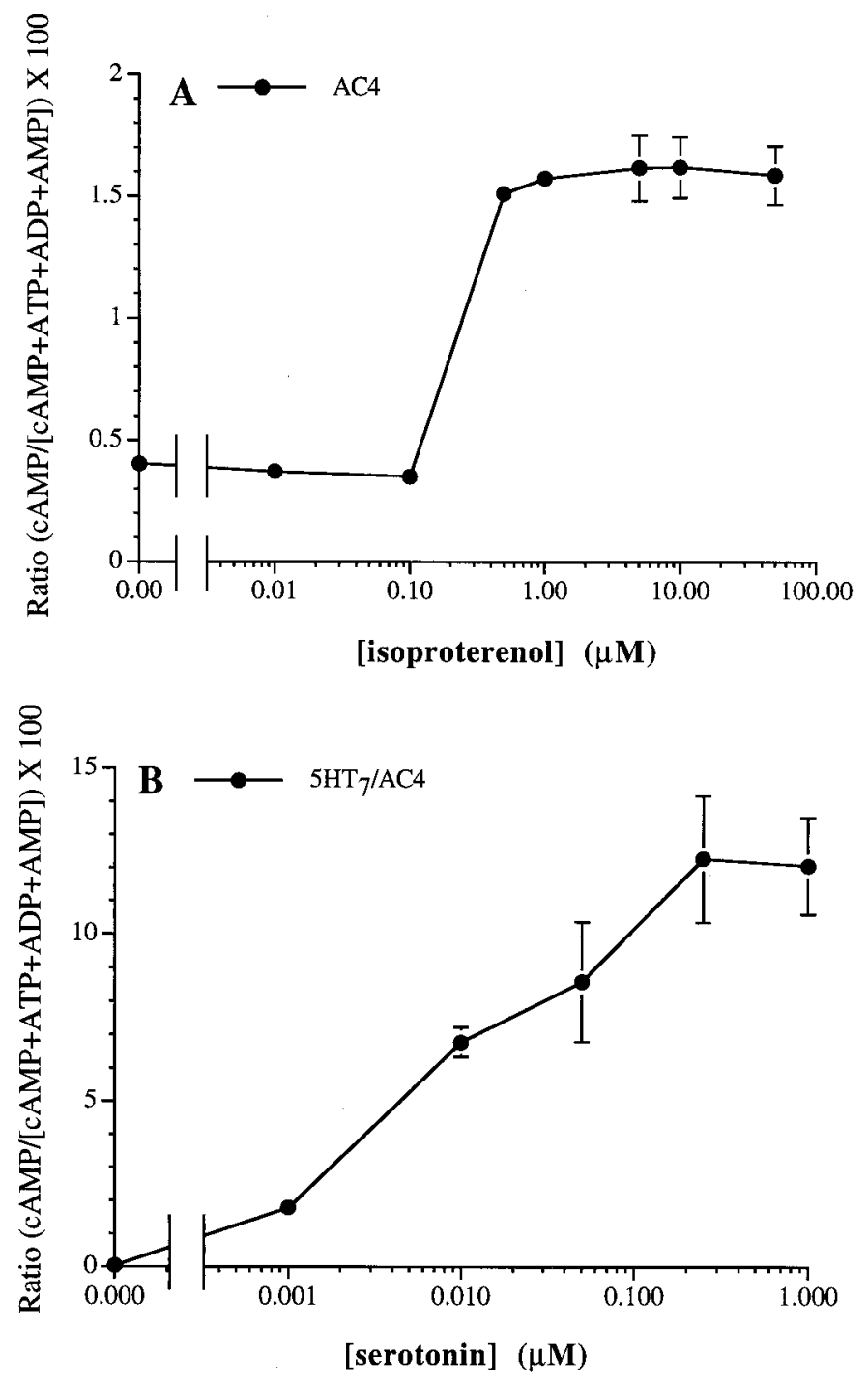

Figure 1. $\mathrm{G}_{\mathrm{s}}$-coupled receptors stimulate AC4 in HEK 293 cells. A, HEK 293 cells stably expressing AC4 were treated with increasing concentrations of isoproterenol. $B$, HEK 293 cells stably coexpressing AC4 with the $\mathrm{G}_{\mathrm{s}}$-coupled 5- $\mathrm{HT}_{7}$ receptor were treated with increasing concentrations of serotonin. Relative cAMP accumulation was determined as described in Materials and Methods, and endogenous HEK 293 cell cAMP accumulation was subtracted from the cAMP measured in AC4expressing cells. The data are the means \pm SD of triplicate assays.

and streptomycin and $10 \%$ BCS and were maintained for $24 \mathrm{hr}$. The following day, cells were split and seeded onto 12-well culture dishes (one transfected plate per 12-well dish) for cAMP assays as well as onto 12 -well plates (two wells per transfection) for $\beta$-galactosidase assays (see below). The next morning, cells used for cAMP assays were labeled for 4-6 hr with $2-3 \mu \mathrm{Ci}$ of $\left[{ }^{3} \mathrm{H}\right]$ adenine (ICN) per well. Just before the cAMP assay, companion cells for the $\beta$-galactosidase assays were lysed and harvested in $500 \mu \mathrm{l}$ of buffer $\mathrm{B}\left(100 \mathrm{~mm} \mathrm{KH}_{2} \mathrm{PO}_{4}, \mathrm{pH} 7.8,0.2 \%\right.$ Triton $\mathrm{X}-100$, and $1 \mathrm{~mm}$ DTT) and frozen until use. cAMP and $\beta$-galactosidase assays were performed as described, and all data were normalized to the measured $\beta$-galactosidase signal for each transfection.

$\beta$-Galactosidase assay. Lysates from transiently transfected cells were thawed and centrifuged at $16,000 \times g$ for $10 \mathrm{~min}$. The supernatant $(20 \mu \mathrm{l})$ was combined with $100 \mu \mathrm{l}$ of reaction buffer $\left[100 \mathrm{mM} \mathrm{Na}_{2} \mathrm{HPO}_{4}, \mathrm{pH} 8.0\right.$, $1 \mathrm{mM} \mathrm{MgCl}_{2}, 35 \mathrm{~mm}$ Galacton (Tropix, Bedford, MA), and $100 \mathrm{~mm}$ D-galactose] and incubated in the dark at room temperature for $60 \mathrm{~min}$. During the incubation period, a 10\% solution of Emerald (Tropix) in $0.2 \mathrm{~N} \mathrm{NaOH}$ was prepared for subsequent addition to the samples at $5 \mathrm{sec}$ intervals by a Berthold luminometer. Each well of lysed cells was assayed 


\section{8}
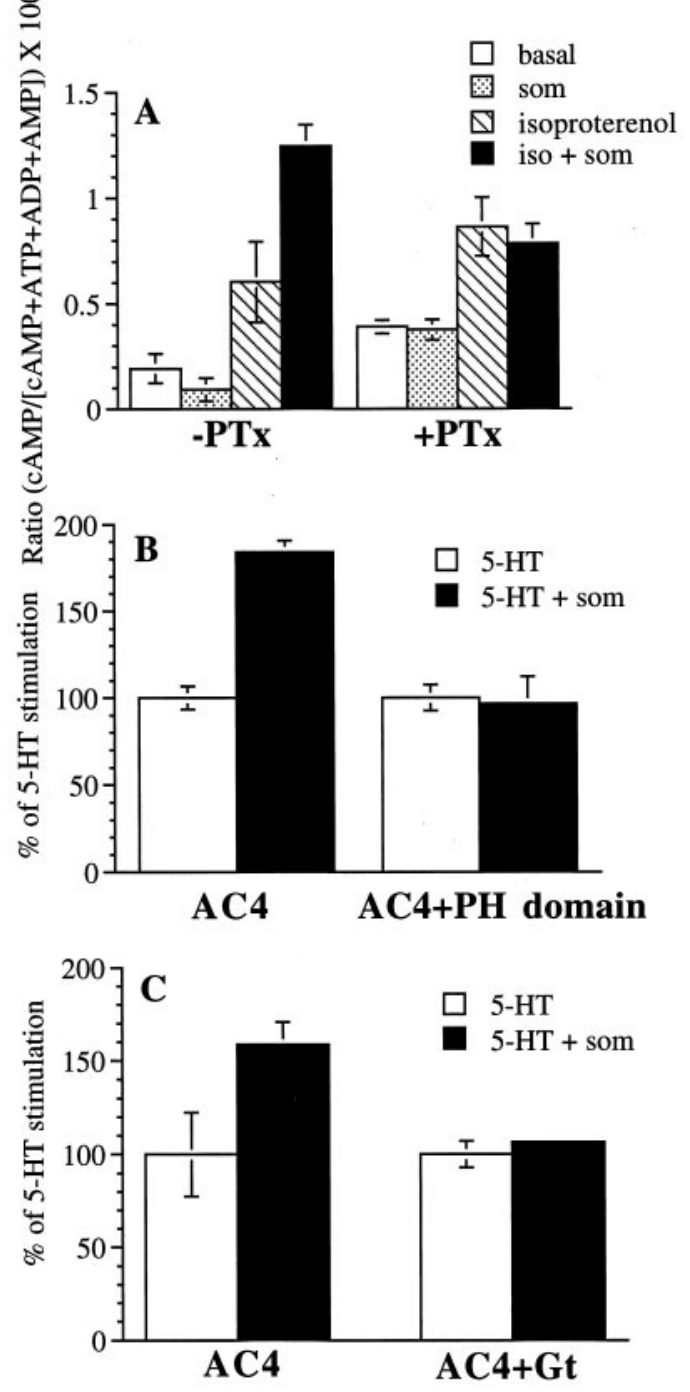

Figure 2. Pertussis toxin, $\beta \mathrm{ARK}_{1} \mathrm{PH}$ domain peptide expression, and transducin $\alpha\left(\mathrm{G}_{\mathrm{t}}\right)$ expression block $\mathrm{G}_{\mathrm{i}}$-coupled receptor potentiation of $\mathrm{G}_{\mathrm{s}}$-stimulated AC4. A, HEK 293 cells stably expressing AC4 were incubated overnight with vehicle $(-P T x)$ or $200 \mathrm{ng} / \mathrm{ml}$ pertussis toxin $(+P T x)$. The following day, cells were treated with vehicle or $10 \mu \mathrm{M}$ isoproterenol (iso) in the presence or absence of $500 \mathrm{~nm}$ somatostatin (som). Relative cAMP accumulation was determined as described in Materials and Methods. The data are the means \pm SD of triplicate assays. B, HEK 293 cells were transiently transfected with RSV- $\beta$-galactosidase and the $5-\mathrm{HT}_{7 \mathrm{~A}}$ receptor, along with either pCDNAIII or the $\beta \mathrm{ARK}_{1} \mathrm{PH}$ domain and either pCEP4 or pCEP4-AC4 as described in Materials and Methods. Cells transfected with the $\beta \mathrm{ARK}_{1} \mathrm{PH}$ domain are denoted $\mathrm{PH}$ domain. AC4-transfected cells with or without the $\mathrm{PH}$ domain were treated with 10 $\mu \mathrm{M}$ serotonin in the presence or absence of $500 \mathrm{nM}$ somatostatin. 5-HTstimulated activity did not differ significantly between AC4-transfected and AC4- and PH domain-transfected cells; the ratio value for AC4 cells in response to 5-HT alone was $2.088 \pm 0.389$ and for AC4 and PH domain cells was $3.565 \pm 0.688$. $C$, Cells were transiently transfected with RSV$\beta$-galactosidase and the $5-\mathrm{HT}_{7 \mathrm{~A}}$ receptor, along with either pCDNAIII or transducin $\alpha$ and either pCEP4 or pCEP4-AC4 as described in Materials and Methods. Cells transfected with transducin $\alpha$ are denoted Gt. Cells were treated with $1 \mu \mathrm{M}$ serotonin in the presence or absence of $500 \mathrm{nM}$ somatostatin. 5-HT-stimulated activity did not differ significantly between AC4-transfected and AC4- and Gt-transfected cells; the ratio value for AC4 cells in response to $5-\mathrm{HT}$ alone was $0.630 \pm 0.292$ and for AC4 and Gt cells was $0.622 \pm 0.091$. For $B$ and $C$, relative cAMP accumulation was determined as described in Materials and Methods. The data are expressed as percent cAMP accumulation in the absence of somatostatin, with this level being set as $100 \%$. The fold stimulation over the basal
A.

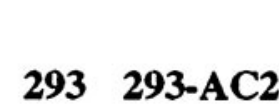

B.

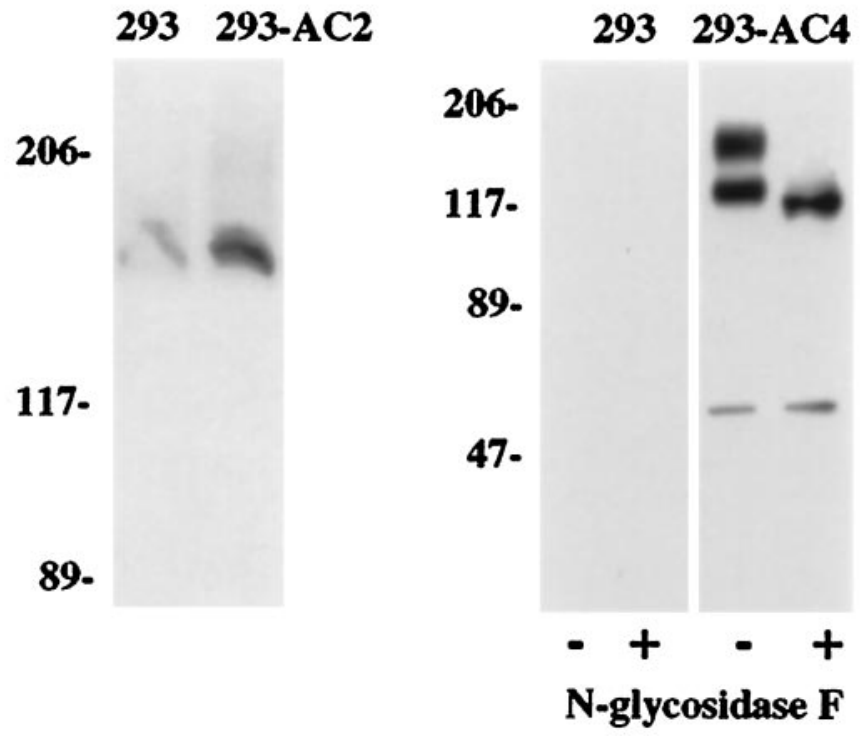

Figure 3. Western blot detection of AC2 and AC4 in HEK 293 cell membranes. $A$, Whole-cell lysate from HEK 293 cells expressing the pCEP4 vector alone (293) or AC2-pCEP4 (293-AC2) was subjected to native PAGE conditions and Western blotted as described in Materials and Methods. Blots were developed using enhanced chemiluminescence and scanned on a Hewlett-Packard Scan Jet II CX scanner. $B$, Membranes from HEK 293 cells were prepared and treated with or without $\mathrm{N}$-glycosidase $\mathrm{F}$ as described in Materials and Methods. Twenty micrograms of membranes from 293-pCEP4 cells (293; lanes 1 and 2) and 293-AC4 cells (293-AC4; lanes 3 and 4) were separated by SDS-PAGE on $7.5 \%$ acrylamide gels. Protein was transferred to nitrocellulose and incubated with anti-AC4 antibody. Molecular weight markers equal 206, 117, 89 , and $47 \mathrm{kDa}$. Note the conversion of the glycosylated form(s) to the lower molecular weight nonglycosylated form after treatment with $\mathrm{N}$-glycosidase F. A minor band at $\sim 60 \mathrm{kDa}$ is only seen in AC4-expressing cells and is therefore probably a proteolytic fragment of AC4 that is recognized by the AC4 antibody.

in duplicate, and the data were used to normalize for transfection efficiency.

Description of $A C 2$ and $A C 4$ antibodies. The anti-AC2 and -AC4 antibodies generated by Santa Cruz Biotechnology are rabbit polyclonal antibodies generated against 20 amino acid peptides corresponding to unique intracellular C-terminal amino acid sequences in AC2 and AC4, respectively. The sequence used to generate the $\mathrm{AC} 2$ antibody corresponds to amino acids 1071-1090 (KTYFVNTEMSRSLSQSNLAS) of rat $\mathrm{AC} 2$, which is $95 \%$ identical to the corresponding human sequence. The sequence used to generate the AC4 antibody corresponds to amino acids 1045-1064 (QLCTYFLNTDLTRTGSPSAS) of rat AC4. Database searches using GCG Blast revealed high-score matches only to rat and human $\mathrm{AC} 2$ for the $\mathrm{AC} 2$ antigen peptide and to rat $\mathrm{AC} 4$ for the $\mathrm{AC} 4$ antigen peptide.

Western blot analysis of AC2 and AC4 expression in HEK 293 cells. HEK 293 cells expressing the pCEP4 vector alone or cells stably transfected with $\mathrm{AC} 2$ or $\mathrm{AC} 4$ were grown to confluence in $100 \mathrm{~mm}$ culture dishes and harvested in $20 \mathrm{~mm}$ Tris $\mathrm{HCl}, \mathrm{pH}$ 7.4, 1 mm EDTA, $2 \mathrm{~mm} \mathrm{MgCl}_{2}, 0.5 \mathrm{~mm}$ DTT, $0.5 \mathrm{~mm}$ PMSF, $3.2 \mu \mathrm{g} / \mathrm{ml}$ leupeptin, $2 \mu \mathrm{g} / \mathrm{ml}$ aprotinin, and 0.5 $\mu \mathrm{g} / \mathrm{ml}$ pepstatin A. Homogenates were centrifuged at $600 \times g$ for $5 \mathrm{~min}$, and the supernatant was retained and centrifuged at $90,000 \times g$ for 30 min. Membrane pellets were resuspended in buffer C $(1 \%$ NP- $40,50 \mathrm{~mm}$ sodium phosphate, $\mathrm{pH}$ 7.4, 10 mм EDTA, 1 mм DTT, $2 \mathrm{~mm} \mathrm{MgCl}_{2}, 0.5$

$\leftarrow$

activity was similar between transfections with or without the PH domain or transducin $\alpha$. The data are the means \pm SD of triplicate assays and were subtracted for endogenous (pCEP4-transfectant) cAMP accumulation and corrected for transfection efficiency using $\beta$-galactosidase. 


\section{AC2 Antibody}
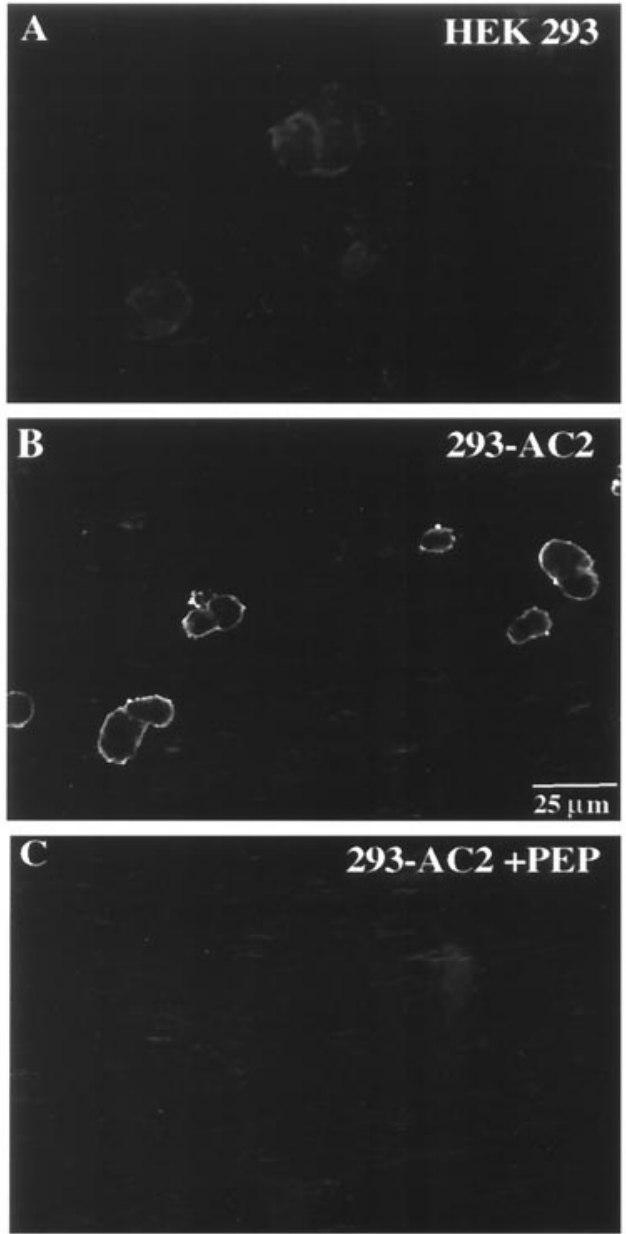

D

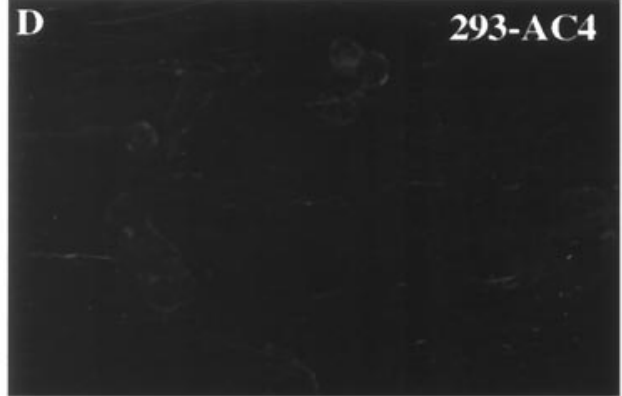

\section{AC4 Antibody}
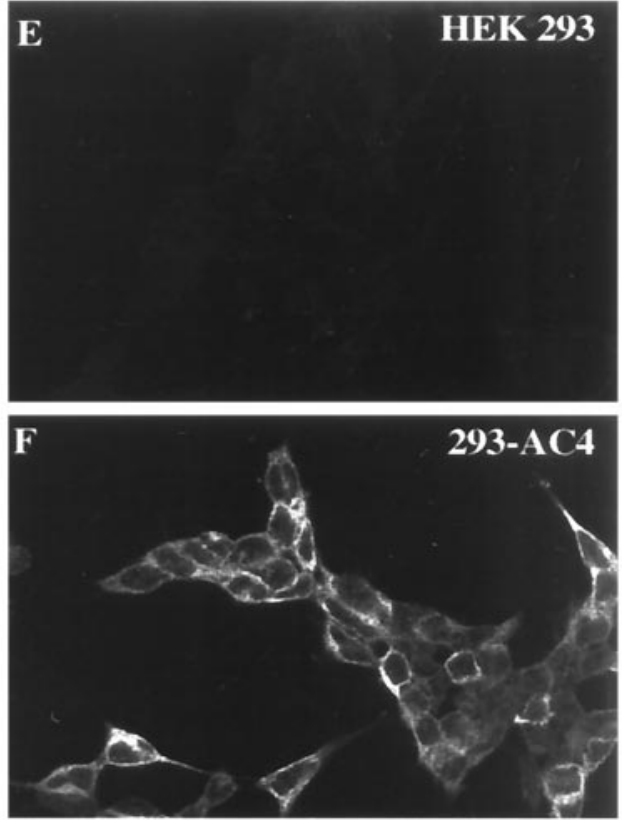

G

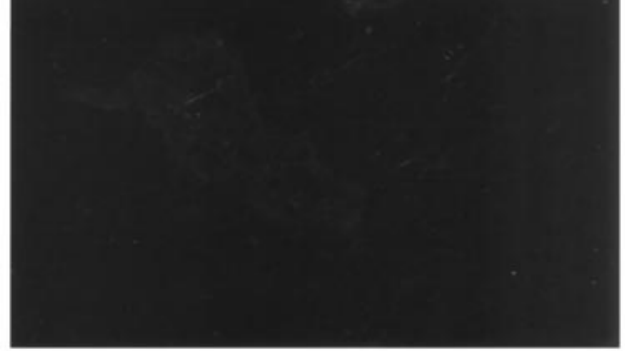

H
293-AC2

Figure 4. Immunocytochemical detection of AC2 and AC4 stably expressed in HEK 293 cells. $A, E$, HEK 293 cells transfected with the pCEP4 vector (designated $H E K$ 293) were processed for immunocytochemistry with the $\mathrm{AC} 2(A)$ or $\mathrm{AC} 4(E)$ antibody as described in Materials and Methods. $B, F$, HEK 293 cells expressing AC2 or AC4 (designated 293-AC2 or 293-AC4) were labeled with the $\mathrm{AC} 2(B)$ or $\mathrm{AC} 4(F)$ antibody. $C$, Adsorption of the AC2 antibody with $\mathrm{AC} 2$ peptide antigen $(P E P)$ blocked AC2 immunolabeling in HEK 293 cells expressing AC2. D, Cells expressing AC4 did not label with the AC2 antibody. $G$, Adsorption of the AC4 antibody with AC4 peptide antigen blocked AC4 immunolabeling in HEK 293 cells expressing AC4. $H$, Cells expressing AC2 did not label with the AC4 antibody. Scale bar, $25 \mu \mathrm{m}$.

mM PMSF, $5 \mu \mathrm{g} / \mathrm{ml}$ leupeptin, and $2 \mu \mathrm{g} / \mathrm{ml}$ aprotinin) and were used immediately or frozen at $-80^{\circ} \mathrm{C}$ for later use. Protein concentrations were determined according to the method of Bradford, using BSA as a standard (Bradford, 1976). Some AC4 samples were subjected to deglycosylation by N-glycosidase F (Boehringer Mannheim, Indianapolis, IN) before electrophoresis. Twenty microgram samples were resuspended in buffer C, SDS was added to $0.1 \%$, and samples were heated at $95^{\circ} \mathrm{C}$ for 5 min. Samples were deglycosylated with 0.5 units of $\mathrm{N}$-glycosidase $\mathrm{F}$ for $1 \mathrm{hr}$ at $37^{\circ} \mathrm{C}$. The deglycosylation reaction was terminated by addition of Laemmli buffer (Laemmli, 1970). Proteins were separated by native PAGE (for AC2) or SDS-PAGE (for AC4) on 7.5\% acrylamide gels and were subsequently transferred to a polyvinylidene difluoride membrane (AC2) or nitrocellulose (AC4) and blocked with 3\% cold fish gelatin (Sigma) in $20 \mathrm{~mm}$ Tris $\mathrm{HCl}$, pH 7.4, $150 \mathrm{~mm} \mathrm{NaCl}$, and $0.05 \%$ Tween 20 for 1-2 hr at room temperature. Blots were incubated with $100 \mathrm{ng} / \mathrm{ml}$ anti-AC2 or - $\mathrm{AC} 4$ at $4{ }^{\circ} \mathrm{C}$ for $16-20 \mathrm{hr}$ followed by HRP-conjugated goat anti-rabbit IgG for $1 \mathrm{hr}$. Blots were developed by enhanced chemiluminescence (Amersham, Arlington Heights, IL) according to the manufacturer's guidelines.
HEK 293 cell immunocytochemistry. HEK 293 cells alone or stably transfected with AC2 or AC4 were plated onto poly-D-lysine-coated coverslips $(60 \mu \mathrm{g} / \mathrm{ml}$ poly-D-lysine $)$ and grown in appropriate growth medium for 2-4 d. Cells were fixed with $4 \%$ paraformaldehyde in PBS, $\mathrm{pH} 7.4$, for $20 \mathrm{~min}$, rinsed with PBS, and permeabilized and blocked for $1 \mathrm{hr}$ with PBS plus $0.5 \%$ Triton X-100, $4 \%$ cold fish gelatin, and $1 \%$ normal goat serum. Cells were incubated with $100 \mathrm{ng} / \mathrm{ml}$ anti-AC2 or -AC4 in PBS plus $0.5 \%$ cold fish gelatin overnight at $4^{\circ} \mathrm{C}$ on a rocker, rinsed, and then incubated with $1 \mu \mathrm{g} / \mathrm{ml}$ lissamine-rhodamineconjugated goat anti-rabbit IgG for $1 \mathrm{hr}$. After a final rinse, the coverslips were mounted onto slides with Gelmount (Biomedia, Foster City, CA). Where indicated, peptide antigen specific for AC2 or AC4 (Santa Cruz Biotechnology) was included at a 20 -fold molar excess to antibody as a control.

Immunohistochemistry on mouse hippocampal sections. C57Bl/6J mice were killed by decapitation, and the brains were quickly removed. Coronal brain slices $(500 \mu \mathrm{m})$ were cut using a vibratome (Campden Instruments, Leicestershire, UK). Slices were fixed for $4-6 \mathrm{hr}$ with $4 \%$ para- 

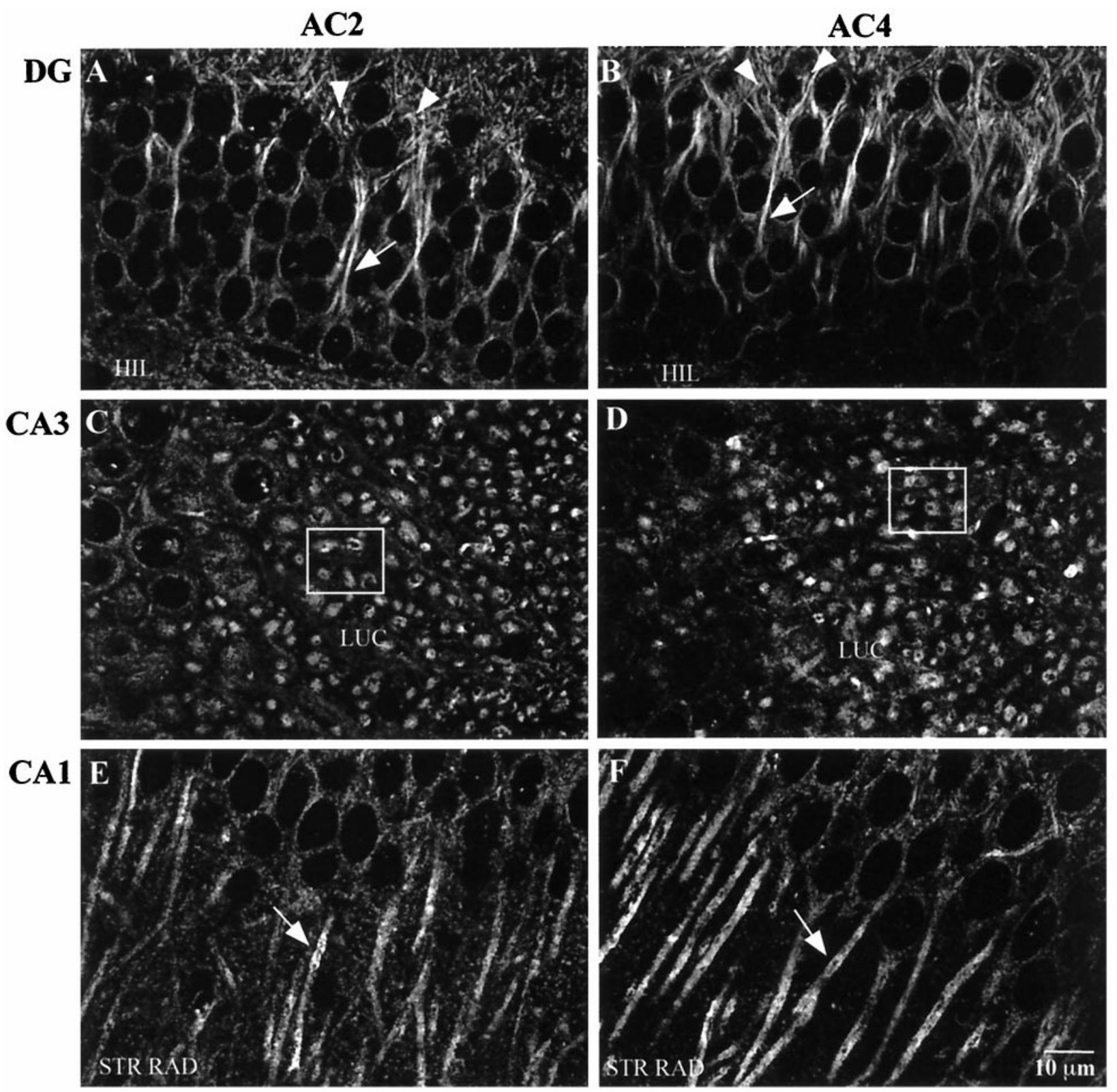

Figure 5. Immunohistochemical detection of AC2 and AC4 in the mouse hippocampal formation. Mouse brain sections (40 $\mu \mathrm{m})$ were processed for immunohistochemistry as described in Materials and Methods. $A, \mathrm{AC} 2$ labeling in the dentate gyrus $(D G)$. $B$, AC4 labeling in dentate gyrus. Note the concentration of AC2 and AC4 label in the proximal dendrites (arrows) and into the dendritic field in the molecular layer (arrowheads). C, AC2 labeling in area CA3. D, AC4 labeling in area CA3. Note the concentration of labeling in the CA3 neuron dendrites in the stratum lucidum (the dendrites are viewed in the coronal plane in these tissue sections). The boxed areas in $C$ and $D$ show specific examples of the described labeling pattern. $E$, AC2 labeling in area CA1. F, AC4 labeling in area CA1. Note the accumulation of label in the CA1 cell bodies and along the membrane of the CA1 dendrites (arrows) in the stratum radiatum. HIL, Hilus; $L U C$, stratum lucidum; STR RAD, stratum radiatum. Scale bar, $10 \mu \mathrm{m}$.

Figure 6. Top. Immunohistochemical detection of AC2 and AC4 in the mouse dentate gyrus. Mouse brain sections ( $40 \mu \mathrm{m})$ were processed for immunohistochemistry as described in Materials and Methods. $A, \mathrm{AC} 2$ labeling (red). B, MAP2 labeling of the same image shown in $A$ (green). $C$, Merged image of $A$ and $B$ (yellow indicates coincident localization). $D, A C 4$ labeling (red). E, MAP2 labeling of the same image shown in $D$ ( $g r e e n$ ). $F$, Merged image of $D$ and $E$ (yellow as described in $C$ ). $C^{\prime}, F^{\prime}$, Higher magnification images of the boxed areas in $C$ and $F$, respectively. Scale bar, 50 $\mu \mathrm{m}$. Boxed areas in $A$ and $B$ correspond to that in $C$. Boxed areas in $D$ and $E$ correspond to that in $F$.

Figure 7. Bottom. Immunohistochemical detection of $\mathrm{AC} 2$ and $\mathrm{AC} 4$ in the $\mathrm{CA} 1$ region of mouse hippocampus. Mouse brain sections (40 $\mu \mathrm{m})$ were processed for immunohistochemistry as described in Materials and Methods. $A$, AC2 labeling (red). $B$, MAP2 labeling of the same image shown in $A$ ( green). $C$, Merged image of $A$ and $B$ (yellow indicates coincident localization). $D$, AC4 labeling (red). E, MAP2 labeling of the same image shown in $D$ (green). $F$, Merged image of $D$ and $E$ (yellow as described in $C$ ). $C^{\prime}, F^{\prime}$, Higher magnification images of the boxed areas in $C$ and $F$, respectively. Scale bar, $50 \mu \mathrm{m}$. Boxed areas in $A$ and $B$ correspond to that in $C$. Boxed areas in $D$ and $E$ correspond to that in $F$. 

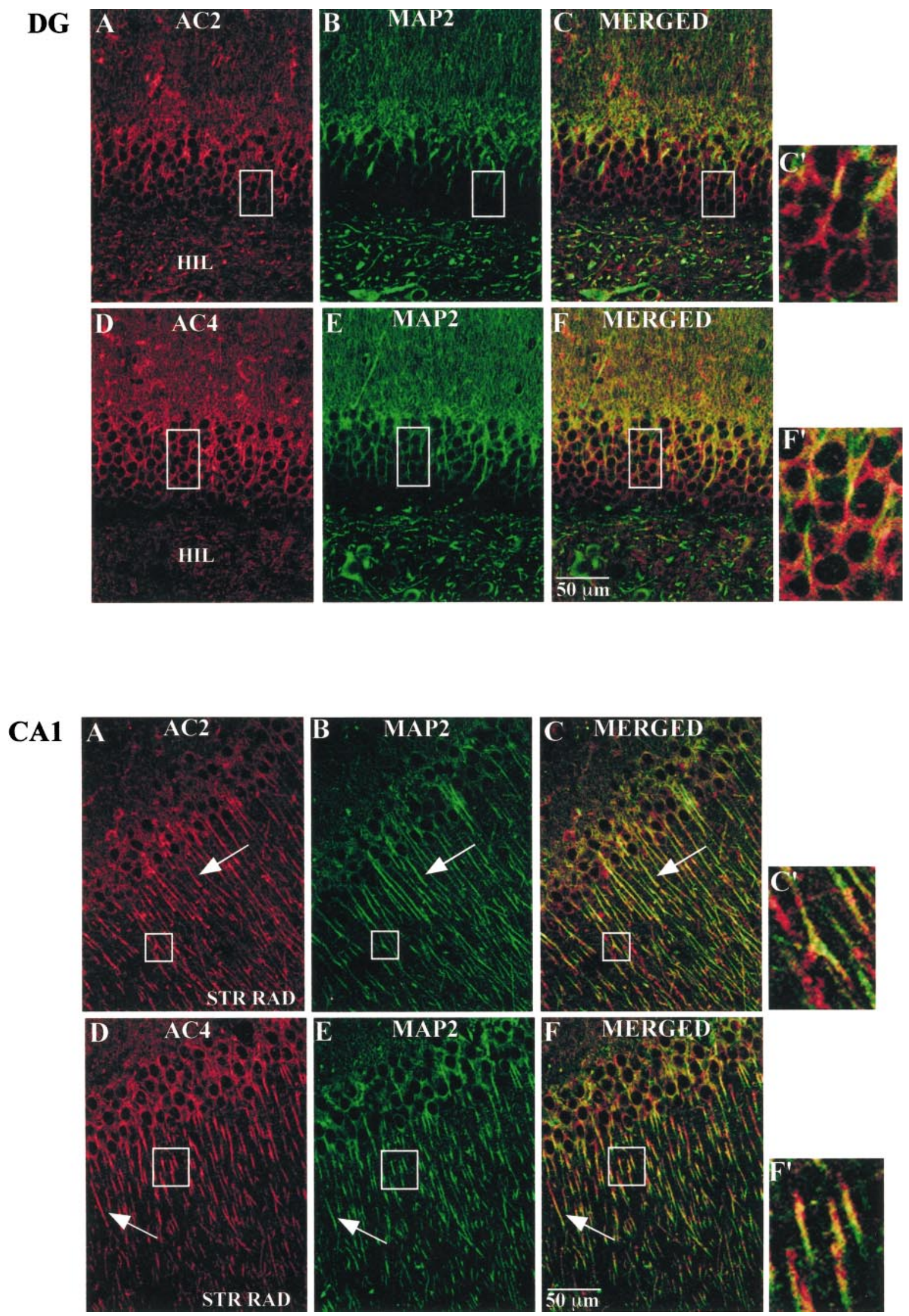
formaldehyde in PBS, $\mathrm{pH}$ 7.4. After fixation, slices were cryoprotected in PBS plus $30 \%$ sucrose and $0.02 \% \mathrm{NaN}_{3}$ and were maintained at $4^{\circ} \mathrm{C}$ until further use. For immunolabeling, $40 \mu \mathrm{m}$ sections were cut from the fixed $500 \mu \mathrm{m}$ slices on a sliding microtome and placed free-floating into a blocking solution of PBS, pH 7.4, plus $0.025 \%$ Triton X-100 (PBST) supplemented with $5 \%$ BSA. Sections were blocked for $1 \mathrm{hr}$ at room temperature and then incubated in PBST plus $0.5 \%$ BSA and 250 or 125 $\mathrm{ng} / \mathrm{ml}$ rabbit polyclonal antibody against AC2 or AC4, respectively, for 18-24 hr. Where indicated, peptide antigens were added at a 20 -fold molar excess to antibody immediately before incubation. After incubation with the primary antibody, sections were washed four times for 10 $\mathrm{min}$ in PBST at room temperature, after which $1 \mu \mathrm{g} / \mathrm{ml}$ lissaminerhodamine-conjugated goat anti-rabbit IgG (Jackson ImmunoResearch, West Grove, PA) was added to the sections for $1 \mathrm{hr}$ at room temperature. Sections were then washed and mounted onto slides using Gelmount (Biomedia) or Vectashield (Vector Laboratories, Burlingame, CA). For double labeling, a $1 \mathrm{hr}$ incubation in a 1:400 dilution of mouse monoclonal anti-synaptophysin (clone SVP-38, ascites fluid; Sigma) or a 1:500 dilution of mouse monoclonal anti-MAP2 (clone HM-2, ascites fluid; Sigma) was followed by incubation in $1 \mu \mathrm{g} / \mathrm{ml}$ FITC-conjugated goat anti-mouse antibody (Jackson ImmunoResearch). Immunolabeling was analyzed using a Bio-Rad MRC 600 confocal microscope (William M. Keck Imaging Center, University of Washington, Seattle, WA). Labeling of discrete brain structures was determined according to the mouse brain atlas of Franklin and Paxinos (1997). Images were processed using Adobe Photoshop 4.0.

\section{RESULTS}

\section{G-protein-coupled receptors stimulate AC4 in intact cells}

HEK 293 cells were transfected with AC4 cDNA, and cells from the stably selected polyclonal cell line were treated with the $\beta$-adrenergic agonist isoproterenol. HEK 293 cells express endogenous $\beta$-adrenergic receptors that couple to stimulation of adenylyl cyclase via $\mathrm{G}_{\mathrm{s}}$ (Impey et al., 1994; Wayman et al., 1994, 1995). Isoproterenol increased cAMP with an $\mathrm{EC}_{50}$ value of $\sim 200$ nM. Maximal stimulation occurred at $1 \mu \mathrm{M}$ (Fig. $1 A$ ). The sharp isoproterenol dose-response curve may reflect isoproterenol oxidation, yielding a threshold effect at $1 \mu \mathrm{M}$ isoproterenol. cAMP was also measured in response to serotonin in 293-AC4 cells stably coexpressing the $\mathrm{G}_{\mathrm{s}}$-coupled $5-\mathrm{HT}_{7 \mathrm{~A}}$ receptor (Shen et al., 1993). cAMP accumulation in nontransfected cells was subtracted from the 293-AC4 value. Serotonin increased cAMP with an $\mathrm{EC}_{50}$ value of $\sim 8 \mathrm{nM}$ and with maximal stimulation at $250 \mathrm{~nm}$ serotonin (Fig. 1B). The extended dose-response curve for 5-HT was observed consistently and may be attributable to differential properties of overexpressed transfected $\left(5-\mathrm{HT}_{7 \mathrm{~A}}\right)$ versus endogenous ( $\beta$-adrenergic) receptors. These data demonstrate that AC4 is stimulated by activation of $\mathrm{G}_{\mathrm{s}}$-coupled receptors in vivo.

\section{$\mathrm{G}_{\mathrm{i}}$-mediated potentiation is inhibited by pertussis toxin and by $\boldsymbol{\beta} \boldsymbol{\gamma}$-binding peptides}

G-protein $\beta \gamma$ subunits potentiate $\mathrm{G}_{\mathrm{s} \alpha}$ stimulation of AC2 (Tang and Gilman, 1991) and AC4 (Gao and Gilman, 1991) in vitro. To determine whether $\mathrm{G}_{\mathrm{i}}$ stimulates AC4 in vivo, we treated HEK
293 cells expressing AC4 with somatostatin in the presence or absence of pertussis toxin. Endogenous somatostatin receptors expressed in HEK 293 cells activate $G_{i}$ and inhibit adenylyl cyclases (Nielsen et al., 1996). Pertussis toxin catalyzes the ADPribosylation of the $\mathrm{G}_{\mathrm{i}} / \mathrm{G}_{\mathrm{o}}$ class of $\mathrm{G}$-proteins (Katada and $\mathrm{Ui}$, 1982; Burns et al., 1983; Hsia et al., 1984; Neer et al., 1984) leading to uncoupling of the receptor and $G_{i}$ (West et al., 1985). Recognition of the heterotrimer and ADP-ribosylation of the $\alpha$ subunit prevent the subsequent release of the $\beta \gamma$ subunit (for review, see Gierschik, 1992). In cells not treated with pertussis toxin, isoproterenol stimulated AC4 threefold. Somatostatin alone induced a slight inhibition of basal activity and did not stimulate AC4. However, coapplication of isoproterenol and somatostatin produced a synergistic increase in cAMP over that observed in response to isoproterenol alone (Fig. 2A). Pertussis toxin treatment increased basal activity, and the somatostatin potentiation of isoproterenol-stimulated cAMP was completely blocked (Fig. 2A). These results indicate that somatostatin enhancement of AC4 activation is caused by $\mathrm{G}_{\mathrm{i}}$.

To determine whether somatostatin increases AC4 activity by stimulating the release of $\beta \gamma$ from $\mathrm{G}_{\mathrm{i}}$, we performed transient transfections of HEK 293 cells in which the $\mathrm{G}_{\mathrm{s}}$-coupled 5-HT receptor and $\mathrm{AC} 4$ were cotransfected with a construct encoding the $\beta \gamma$-binding, $\mathrm{C}$-terminal region of $\beta$-adrenergic receptor $\mathrm{ki}$ nase 1 (referred to here as the pleckstrin homology or $\mathrm{PH}$ domain). Cellular expression of this $\mathrm{PH}$ domain can attenuate the effect of $\beta \gamma$ on the MAP kinase pathway and phospholipase C (Inglese et al., 1994; Koch et al., 1994; Luttrell et al., 1995). In cells transfected with $5-\mathrm{HT}_{7 \mathrm{~A}}, \mathrm{AC} 4$, and the empty vector for the $\mathrm{PH}$ domain, somatostatin potentiated serotonin stimulation of AC4 by $\sim 80 \%$ (Fig. $2 B$ ). When the PH domain was coexpressed, somatostatin potentiation of $\mathrm{G}_{\mathrm{s}}$-stimulated AC4 was completely abolished (Fig. 2B). Similar results were obtained using a cotransfected using a cotransfected transducin $\alpha$ subunit as a $\beta \gamma$ scavenger. Coexpression of transducin $\alpha\left(\mathrm{G}_{\mathrm{t}}\right)$ with AC4 and the 5-HT receptor inhibited somatostatin-mediated potentiation of serotonin-induced cAMP levels (Fig. 2C). These data suggest that somatostatin stimulation of $\mathrm{G}_{\mathrm{s}}$-activated AC4 activity is caused by $\beta \gamma$ release from $\mathrm{G}_{\mathrm{i}}$.

\section{Characterization of $\mathrm{AC2}$ and AC4 antibodies in HEK 293 cells}

Before determining the expression of AC2 and AC4 in the hippocampus, we characterized the specificity of the AC2 and AC4 polyclonal antibodies by Western blot and immunolabeling studies. By Western blot, the AC2 antibody recognized AC2 overexpressed in HEK 293 cells under native conditions and very little under denaturing conditions (Fig. 3A). HEK 293 cells express low levels of AC2 endogenously (Hellevuo et al., 1993). Accordingly the AC2 antibody also recognized a low level of AC2 in nontransfected cells (Fig. $3 A$ ). The specificity of the AC4 antibody was also

\footnotetext{
Figure 8. Top. Immunohistochemical localization of AC2 and AC4 relative to synaptophysin in the mouse dentate gyrus. Mouse brain sections (40

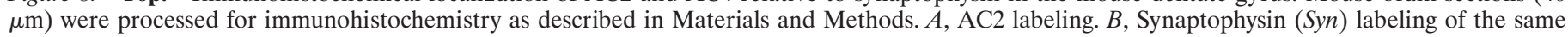

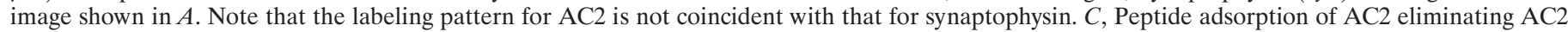

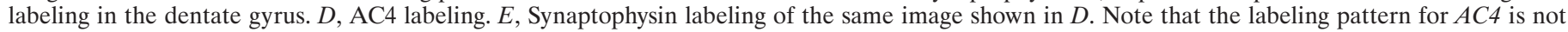
coincident with that for synaptophysin. F, Peptide adsorption of AC4 eliminating AC4 labeling in the dentate gyrus. Scale bar, $50 \mu \mathrm{m}$.

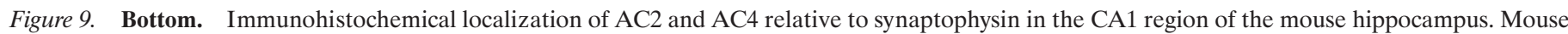

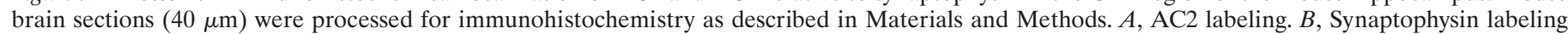

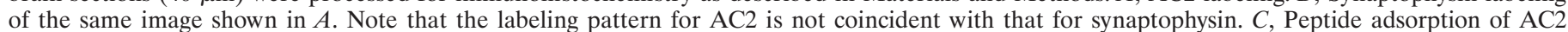

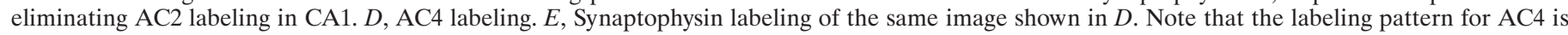
not coincident with that for synaptophysin. $F$, Peptide adsorption of AC4 eliminating AC4 labeling in CA1. Scale bar, $50 \mu$ m.
} 

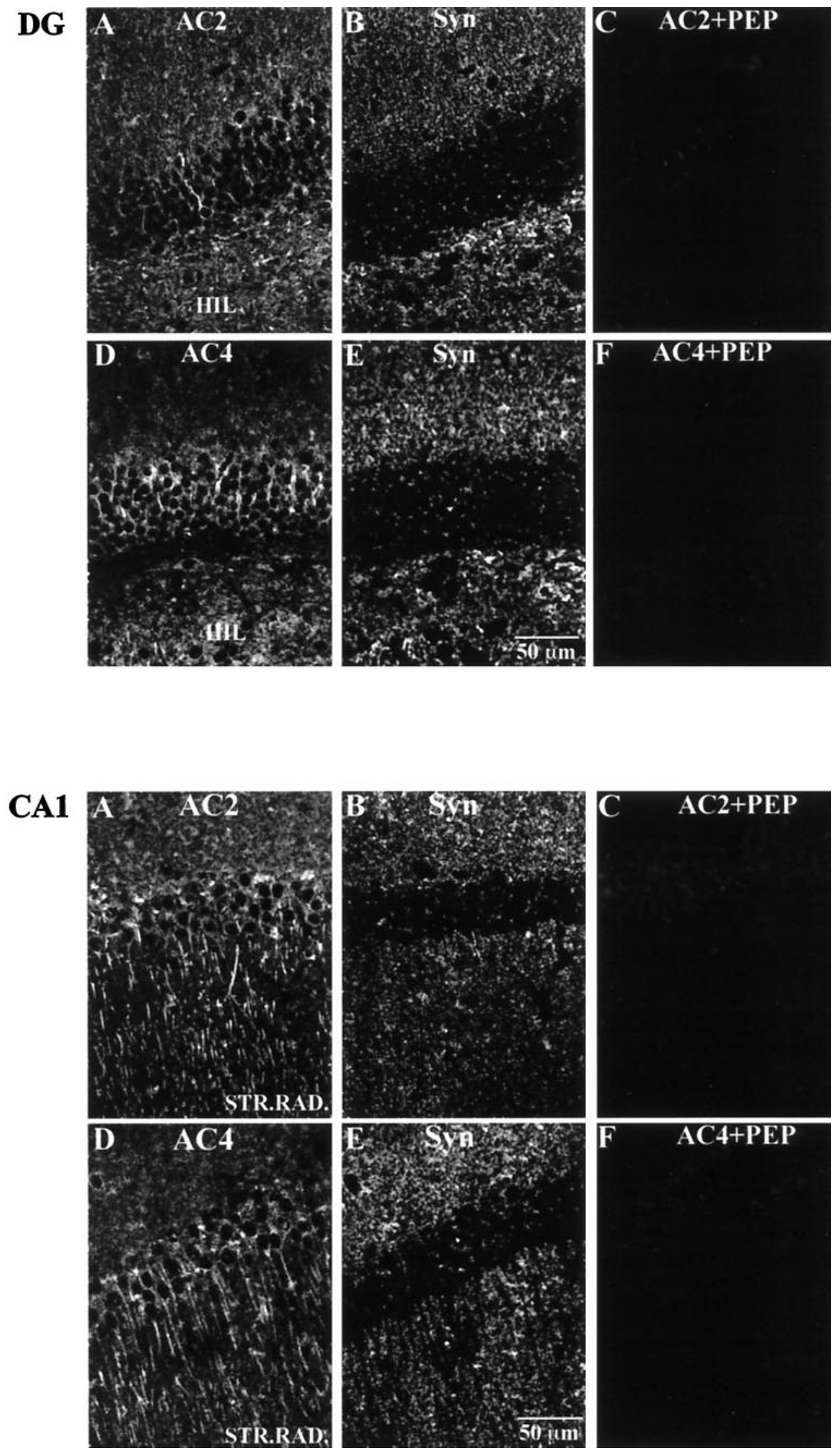
analyzed by Western blot (Fig. 3B). Untransfected HEK 293 cells showed no immunoreactive bands, whereas cells overexpressing AC4 showed bands at $\sim 110$ and $150 \mathrm{kDa}$. Treatment with $\mathrm{N}$-glycosidase F shifted the $150 \mathrm{kDa}$ band to the lower molecular weight, indicating that the lower band corresponds to non- or subglycosylated AC4. A minor band detected at $\sim 60 \mathrm{kDa}$ was observed in AC4-expressing cells only and is likely a proteolytic fragment of AC4 that is also recognized by the AC4 antibody.

Immunolabeling studies using untransfected HEK 293 cells or cells expressing AC2 or AC4 were also performed (Fig. 4). The AC2 antibody produced a low level of labeling in HEK 293 cells transfected with the empty expression vector (Fig. $4 A$ ). In contrast, pronounced membrane labeling was observed in cells stably expressing AC2 (Fig. 4B), which was completely abrogated after AC2 peptide adsorption (Fig. $4 C$ ). No AC2 labeling over endogenous levels was observed in AC4-expressing cells (Fig. 4D). Similarly, the AC4 antibody labeled cells expressing AC4 (Fig. $4 F$ ) but not vector-transfected cells (Fig. $4 E$ ) or cells expressing AC2 (Fig. 4H). Adsorption of the AC4 antibody with the AC4 peptide blocked all immunolabeling with the AC4 antibody (Fig. $4 G)$. The AC2 and AC4 antibodies also did not recognize other adenylyl cyclases (AC1, AC3, AC5, AC6, AC8, and AC9) expressed in HEK 293 cells (data not shown).

\section{Analysis of AC2 and AC4 expression in mouse hippocampal formation}

To define the expression and localization of AC2 and AC4 proteins in the mouse hippocampal formation, we performed immunhistochemical studies. The AC4 antibody was also used to immunoprecipitate AC4 from mouse hippocampal membranes (data not shown). The AC2 antibody was not useful for immunoprecipitation. For immunohistochemistry, $40 \mu \mathrm{m}$ hippocampal slices were labeled using either the AC2 or AC4 antibody and were examined by confocal microscopy. Specific labeling for both adenylyl cyclase isoforms was observed throughout the hippocampal formation, and the labeling pattern was more or less indistinguishable for both AC2 and AC4. In the dentate gyrus, immunolabeling for $\mathrm{AC} 2$ and $\mathrm{AC} 4$ was concentrated in the proximal dendrites of the granule cells and extended into the dendritic field in the molecular layer (Fig. 5A,B). A lower level of labeling was also observed in the cell bodies. Double labeling was performed for AC2 or AC4 and either a dendritic marker (MAP2; Figs. 6, 7) or a synaptic terminal marker (synaptophysin; Figs. 8, 9). AC signal was coincident with the MAP2 labeling in the dendrites (Fig. 6C,F, $C^{\prime}, F^{\prime}$; yellow indicates coincident signal) and did not colocalize at all with the synaptophysin signal (Fig. 8), indicating a postsynaptic localization of these adenylyl cyclase isoforms. Scattered cells in the hilus were also labeled using the AC2 and AC4 antibodies.

In area $\mathrm{CA} 3$, labeling for both $\mathrm{AC} 2$ and $\mathrm{AC} 4$ was concentrated in short, coronally sectioned CA3 pyramidal cell dendrites throughout the stratum lucidum (Fig. $5 C, D$ ). Upon closer examination, the labeling was coincident with MAP2 signal (Fig. $\left.10 C, F, C^{\prime}, F^{\prime}\right)$. Similar to the pattern observed in the dentate gyrus, the labeling pattern was not colocalized with synaptophysin signal (Fig. $11 C, F, C^{\prime}, F^{\prime}$ ). In fact, the adenylyl cyclase label appeared in many instances to be surrounded by synaptophysin labeling, similar to what has been described (Lim et al., 1997) where several mossy fiber synaptic terminals or a single large terminal impinge on a given dendritic region. There was very little labeling for AC2 or AC4 in the CA3 pyramidal cell bodies.

In area CA1, immunofluorescence for both $\mathrm{AC} 2$ and $\mathrm{AC} 4$ was concentrated along the apical dendrites throughout the stratum radiatum, with some labeling in the CA1 pyramidal cell bodies as well (Fig. $5 E, F$ ). As with the labeling in the dentate gyrus and $\mathrm{CA} 3$, the signal was coincident with the signal for the postsynaptic marker MAP2 (Fig. $7 C, F, C^{\prime}, F^{\prime}$ ) and was not colocalized with labeling for synaptophysin (Fig. 9). Very little labeling was seen in the processes in the stratum oriens, although occasional small cell bodies did label for AC2 or AC4. The labeling for AC2 and AC4 throughout the hippocampal formation was completely blocked by adsorption with the appropriate peptide antigen (Figs. $8 C, F$, $9 C, F)$. Double labeling for AC2 and AC4 in the same tissue sections using a combination of fluorophore-labeled IgG and Fab fragments demonstrated that $\mathrm{AC} 2$ and $\mathrm{AC} 4$ are expressed in a very similar manner in the mouse hippocampal formation (data not shown). The only consistent difference in labeling was a slightly higher level of AC2 over AC4 signal in the dentate gyrus granule somas (Fig. 5A,B).

Immunohistochemical labeling for AC4 was also observed in several forebrain regions. In the neocortex and piriform cortex, a moderate percentage of neurons were labeled and included pyramidal cell bodies and dendrites (data not shown). Discrete labeling of neurons in the septum, medial habenular nucleus, induseum griseum, and the paraventricular thalamic nucleus was also seen (data not shown).

\section{DISCUSSION}

Each of the adenylyl cyclase isoforms possesses distinct regulatory properties, and all of the cloned mammalian adenylyl cyclases are expressed in the brain. Therefore, cAMP levels in neurons can be modulated by a variety of signals, including receptor activation, changes in intracellular $\mathrm{Ca}^{2+}$, and activation of protein kinases (for review, see Sunahara et al., 1996). Of particular interest are adenylyl cyclases that integrate coincident signals from different upstream pathways. For example, AC1 is synergistically stimulated by $\mathrm{G}_{\mathrm{s}}$-coupled receptors and $\mathrm{Ca}^{2+}$ (Impey et al., 1994; Wayman et al., 1994) and contributes to mossy fiber-CA3 LTP (Villacres et al., 1998). Other examples include the

\footnotetext{
Figure 10. Top. Immunohistochemical localization of AC2 and AC4 with MAP2 in the CA3 region of the mouse hippocampus. Mouse brain sections $(40 \mu \mathrm{m})$ were processed for immunohistochemistry as described in Materials and Methods. $A, \mathrm{AC} 2$ labeling (red). $B$, MAP2 labeling of the same image shown in $A$ (green). $C$, Merged image of $A$ and $B$ (yellow indicates coincident localization of AC2 and MAP2). D, AC4 labeling (red). E, MAP2 labeling of the same image shown in $D$ (green). $F$, Merged image of $D$ and $E$ (yellow as described in $C$ ). $C^{\prime}, F^{\prime}$, Higher magnification images of the boxed areas in $C$ and $F$, respectively. Scale bar, $50 \mu \mathrm{m}$. Boxed areas in $A$ and $B$ correspond to that in $C$. Boxed areas in $D$ and $E$ correspond to that in $F$.

Figure 11. Bottom. Immunohistochemical localization of AC2 and AC4 with synaptophysin in the CA3 region of mouse hippocampus. Mouse brain sections $(40 \mu \mathrm{m})$ were processed for immunohistochemistry as described in Materials and Methods. $A$, AC2 labeling (red). B, Synaptophysin labeling of the same image shown in $A$ (green). $C$, Merged image of $A$ and $B$ (note lack of yellow labeling, indicating a lack of coincident localization of AC2 and synaptophysin). $D$, AC4 labeling (red). $E$, Synaptophysin labeling of the same image shown in $D$ (green). $F$, Merged image of $D$ and $E$. $C^{\prime}, F^{\prime}$, Higher magnification images of the boxed areas in $C$ and $F$, respectively. Scale bar, $50 \mu \mathrm{m}$. Boxed areas in $A$ and $B$ correspond to that in $C$. Boxed areas in $D$ and $E$ correspond to that in $F$.
} 

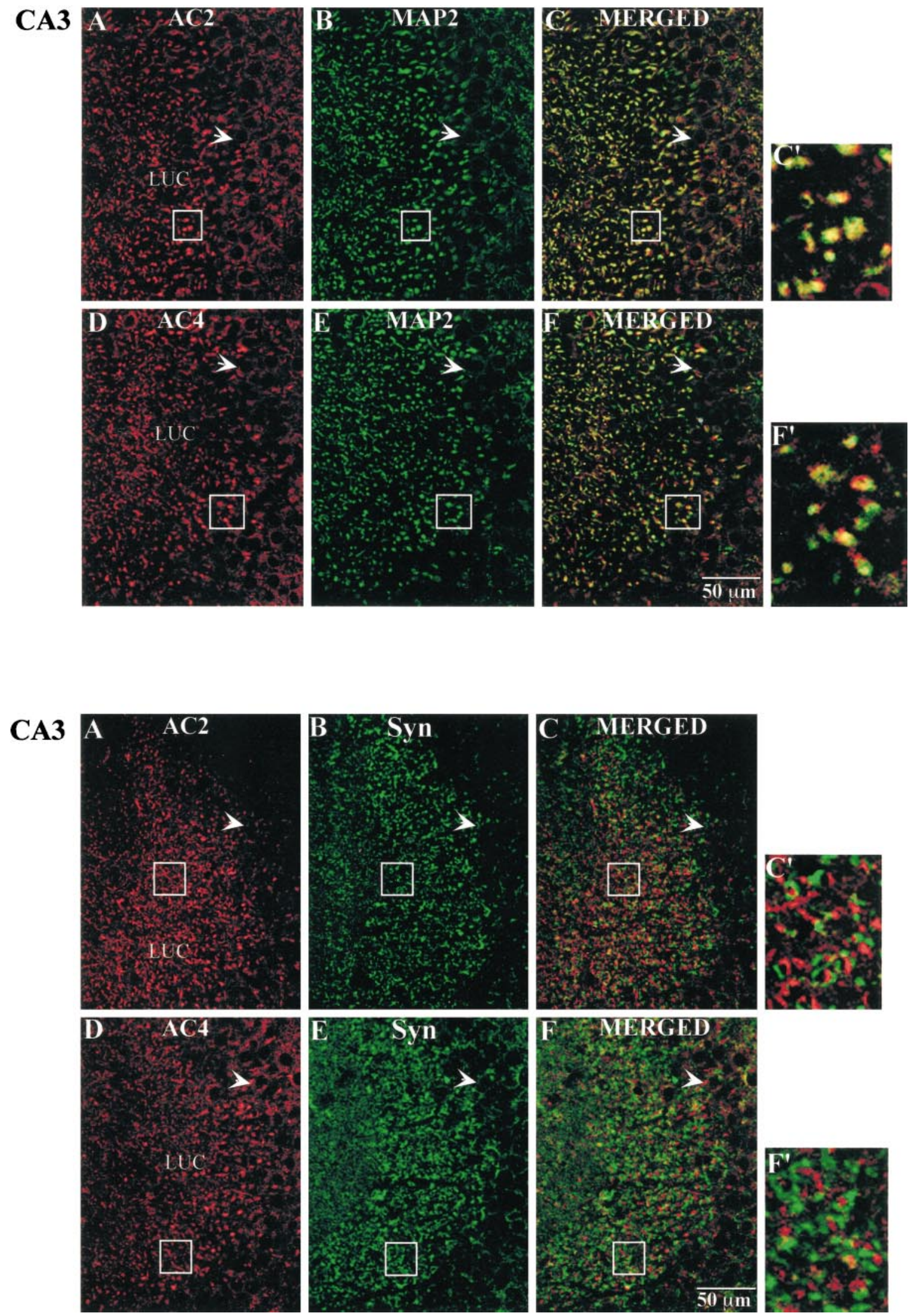
$\beta \gamma$-stimulated adenylyl cyclases, which are synergistically activated by $\mathrm{G}_{\mathrm{s}}$-coupled receptors and $\beta \gamma$ released from $\mathrm{G}_{\mathrm{i}}$-coupled receptors.

Whereas most mammalian tissues express adenylyl cyclase activity that is inhibited by activation of $\mathrm{G}_{\mathrm{i}}$-coupled receptors, in the brain and lung, $\mathrm{G}_{\mathrm{i}}$-coupled receptors actually potentiate $\mathrm{G}_{\mathrm{s}}$ stimulated cAMP production (Andrade, 1993; Gereau and Conn, 1994; Pian and Dobbs, 1995; Olianas et al., 1998). In the hippocampus, in particular, several groups have observed potentiation of $\mathrm{G}_{\mathrm{s}}$-coupled receptor stimulation by $\mathrm{G}_{\mathrm{i}}$-coupled receptors (Andrade, 1993; Gereau and Conn, 1994). The $\mathrm{Ca}^{2+}$-stimulated adenylyl cyclases (AC1 and AC8) are thought to play a role in synaptic plasticity in the hippocampus (Choi et al., 1993; Weisskopf et al., 1994; Wu et al., 1995; Xia et al., 1995; Villacres et al., 1998). However, the detection of mRNA in the hippocampus for at least one $\beta \gamma$-stimulated adenylyl cyclase, AC2 (Furuyama et al., 1993), suggests that there may be additional mechanisms for generating the robust cAMP increases thought to underlie synaptic plasticity. The goals of this research were to determine whether AC4 is stimulated by $\beta \gamma$ subunits in intact cells and to determine the expression and localization of AC2 and AC4 in the hippocampus.

In this study, we demonstrated that AC4 is stimulated by $\mathrm{G}_{\mathrm{s}}$-coupled receptors in intact HEK 293 cells. This is consistent with previous in vitro data (Gao and Gilman, 1991) and recent work by Avidor-Reiss et al. (1997) using COS-7 cells that demonstrated that AC4 is stimulated by recombinant or endogenous $\mathrm{G}_{\mathrm{s} \alpha}$, respectively. Additionally, we found that $\mathrm{G}_{\mathrm{i}}$-coupled receptor activation potentiates the response of AC4 to $G_{s}$-coupled receptors in vivo. Specifically, stimulation of AC4 by $\mathrm{G}_{\mathrm{s}}$-coupled receptors was potentiated by activation of $\mathrm{G}_{\mathrm{i}}$-coupled somatostatin receptors. Somatostatin potentiation of isoproterenolstimulated AC4 was blocked by pertussis toxin. In addition, in transient transfection experiments, coexpression of the $\mathrm{C}$-terminal, $\beta \gamma$-binding region of $\beta \mathrm{ARK}_{1}$ (PH domain) or transducin $\alpha\left(\mathrm{G}_{\mathrm{t}}\right)$ effectively blocked somatostatin potentiation of $5-\mathrm{HT}_{7 \mathrm{~A}}$-stimulated AC4 activity. This indicates that AC4 responds to paired $\mathrm{G}_{\mathrm{s}}$ and $\mathrm{G}_{\mathrm{i}}$ inputs in vivo with $\beta \gamma$ potentiation. Similar findings have been observed for AC2 in vivo (Federman et al., 1992; Lustig et al., 1993; Koch et al., 1994). These results demonstrate that both $\mathrm{AC} 2$ and $\mathrm{AC} 4$ can function as coincidence detectors of paired $G_{s}$ and $G_{i}$ inputs. It has also been demonstrated that $\mathrm{AC} 2$ can detect simultaneous activation of $\mathrm{PKC}$ and $\mathrm{G}_{\mathrm{i}}$ (Tsu and Wong, 1996). It is possible that $\beta \gamma$ potentiation of AC2 could also occur via $\beta \gamma$ activation of phospholipase $C$ (Banno et al., 1998), which then results in the activation of perhaps another PKC isoform. This would not be expected to occur with AC4 because AC4 has been demonstrated to be insensitive to PKC (Jacobowitz et al., 1993). Because coincidence detection of separate, temporally overlapping signals is believed to be important for neuroplasticity (Bourne and Nicoll, 1993), our results suggest a role for $\mathrm{AC} 4$ in addition to $\mathrm{AC} 2$ in synaptic plasticity.

A second aspect of this study was directed at elucidating immunohistochemically the localization of AC2 and AC4 in the mouse hippocampal formation. To this end, we demonstrated that both AC2 and AC4 proteins are expressed in the hippocampus. The immunohistochemical labeling pattern for both AC2 and AC4 was for the most part indistinguishable and colocalized with that for MAP2, a dendritic and/or postsynaptic marker, in all regions of the hippocampal formation. In the dentate gyrus, labeling was found in the proximal dendrites and extended into the dendritic field in the molecular layer. In CA3, AC2 and AC4 immunolabeling was concentrated in the CA3 pyramidal cell dendrites throughout the stratum lucidum. In the CA1 region, AC2 and AC4 labeling was concentrated along the apical dendrites of the pyramidal cells and extended throughout the stratum radiatum. This postsynaptic pattern is similar to that described by Mons et al. (1995) using an antibody generated against a common domain in all adenylyl cyclase isoforms. At least at this level of resolution and compared with the labeling pattern for synaptophysin, AC2 and AC4 are not expressed presynaptically in the hippocampus. These results are the first to demonstrate the localization of AC2 and AC4 proteins in the hippocampus. Double labeling with markers for pre- and postsynaptic sites (synaptophysin and MAP2, respectively) strongly indicate that both AC2 and AC4 are localized postsynaptically along the dendrites in all regions of the hippocampus.

Possible roles for $\beta \gamma$-stimulated adenylyl cyclases in synaptic plasticity are as follows. AC2 may serve to integrate inputs from multiple signaling pathways, because it can respond to either $\mathrm{G}_{\mathrm{s} \alpha}$ or $\mathrm{PKC}$ and $\beta \gamma$ from $\mathrm{G}_{\mathrm{i}}$ with potentiation in vivo (Federman et al., 1992; Lustig et al., 1993; Tsu and Wong, 1996). Additionally, PKC may suppress the responsiveness of AC2 to paired $G_{\mathrm{s} \alpha}$ and $\beta \gamma$ stimulation (Zimmermann and Taussig, 1996). These regulatory features may allow for the generation of cAMP signals with the necessary spatial and temporal characteristics to contribute to long-term changes in synaptic strength (Backsai et al., 1993). Consistent with this notion, mossy fiber-CA3 LTP has been reported to be dependent on activation of $G_{i} / G_{o}$-coupled opioid receptors (Williams and Johnston, 1996) and pertussis toxinsensitive G-proteins (Ito et al., 1988). We have focused on $\beta \gamma$ subunits released from $\mathrm{G}_{\mathrm{i}}$. However, it is possible that $\beta \gamma$ subunits released from $\mathrm{G}_{\mathrm{q}}$ or other pertussis toxin-insensitive $\mathrm{G}$-proteins could facilitate potentiated adenylyl cyclase activity in vivo, as has been postulated to occur in the frontal cortex (Onali and Olianas, 1998).

A possible role for AC4 in synaptic plasticity in the hippocampus may be to integrate $\mathrm{G}_{\mathrm{s}}$ and $\mathrm{G}_{\mathrm{i}}$ inputs, perhaps as a complement to the signal generated by $\mathrm{AC} 2$. The presence of $\mathrm{AC} 2$ and AC4 in the hippocampus thus allows for flexibility in the generation of robust cAMP increases necessary for synaptic plasticity. In addition to relying on the $\mathrm{Ca}^{2+}$-stimulated adenylyl cyclases as a means of eliciting cAMP-mediated long-term adaptive changes, hippocampal neurons may have evolved with several distinct mechanisms for expression of synaptic plasticity. It is possible that there exist two (or more) parallel pathways involving cAMP that encode different forms of synaptic plasticity. With respect to the AC4 immunolabeling observed in the forebrain, it is intriguing that several of these areas are sites in which synaptic plasticity has been demonstrated (e.g., neocortex and piriform cortex) (Hasselmo and Barkai, 1995; Cruikshank and Weinberger, 1996).

In summary, these results demonstrate that AC4 can act as a coincidence detector of paired $\mathrm{G}_{\mathrm{s}}$ and $\mathrm{G}_{\mathrm{i}}$ inputs. The finding that both $\mathrm{AC} 2$ and $\mathrm{AC} 4$ proteins are expressed postsynaptically in hippocampus suggests that these adenylyl cyclase isoforms may play a role in certain forms of hippocampal synaptic plasticity.

\section{REFERENCES}

Andrade R (1993) Enhancement of beta-adrenergic responses by $\mathrm{G}_{\mathrm{i}}$ linked receptors in rat hippocampus. Neuron 10:83-88.

Avidor-Reiss T, Nevo I, Saya D, Bayewitch M, Vogel Z (1997) Opiateinduced adenylyl cyclase superactivation is isozyme-specific. J Biol Chem 272:5040-5047.

Backsai BJ, Hochner B, Mahaut-Smith M, Adams SR, Kaang B-K, 
Kandel ER, Tsien RY (1993) Spatially resolved dynamics of cAMP and protein kinase A subunits in Aplysia sensory neurons. Science 260:222-226.

Bakalyar HA, Reed RR (1990) Identification of a specialized adenylyl cyclase that may mediate odorant detection. Science 250:1403-1406.

Banno Y, Asano T, Nozawa Y (1998) Stimulation by G protein betagamma subunits of phospholipase $\mathrm{C}$ beta isoforms in human platelets. Thromb Haemost 79:1008-1013.

Bourne HR, Nicoll R (1993) Molecular machines integrate coincident synaptic signals. Cell [Suppl] 72:65-75.

Bradford MM (1976) A rapid and sensitive method for the quantification of microgram quantities of protein utilizing the principle of protein-dye binding. Anal Biochem 72:248-254.

Burns DL, Hewlett EL, Moss J, Vaughan M (1983) Pertussis toxin inhibits enkephalin stimulation of GTPase in NG108-15 cells. J Biol Chem 258:1435-1438.

Cali JF, Zwaagstra JC, Mons N, Cooper DMF, Krupinski J (1994) Type VIII adenylyl cyclase. A $\mathrm{Ca}^{2+} /$ calmodulin-stimulated enzyme expressed in discrete regions of rat brain. J Biol Chem 269:12190-12195.

Chen C, Okayama H (1987) High-efficiency transformation of mammalian cells by plasmid DNA. Mol Cell Biol 7:2745-2752.

Choi EJ, Xia Z, Villacres EC, Storm DR (1993) The regulatory diversity of the mammalian adenylyl cyclases. Curr Opin Cell Biol 5:269-273.

Cooper DMF, Mons N, Karpen JW (1995) Adenylyl cyclases and the interaction between calcium and cAMP signalling. Nature 374: 421-424.

Cruikshank SJ, Weinberger NM (1996) Evidence for the Hebbian hypothesis in experience-dependent physiological plasticity of neocortex: a critical review. Brain Res Rev 22:191-228.

Federman AD, Conklin BR, Schrader KA, Reed RR, Bourne HR (1992) Hormonal stimulation of adenylyl cyclase through $\mathrm{G}_{\mathrm{i}}$-protein beta gamma subunits. Nature 356:159-161.

Feinstein PG, Schrader A, Bakalyar HA, Tang WJ, Krupinski J, Gilman AG, Reed RR (1991) Molecular cloning and characterization of a calcium calmodulin insensitive adenylyl cyclase (type II) from rat brain. Proc Natl Acad Sci USA 88:10173-10177.

Franklin KJB, Paxinos G (1997) The mouse brain. San Diego: Academic.

Frey U, Huang YY, Kandel ER (1993) Effects of cAMP simulate a late stage of LTP in hippocampal CA1 neurons. Science 260:1661-1664.

Furuyama T, Inagaki S, Takagi H (1993) Distribution of type II adenylyl cyclase mRNA in the rat brain. Mol Brain Res 19:165-170.

Gao B, Gilman A (1991) Cloning and expression of a widely distributed (type IV) adenylyl cyclase. Proc Natl Acad Sci USA 88:10178-10182.

Gereau RW, Conn PJ (1994) A cyclic AMP-dependent form of associative synaptic plasticity induced by coactivation of $\beta$-adrenergic receptors and metabotropic glutamate receptors in rat hippocampus. J Neurosci 14:3310-3318.

Gierschik P (1992) ADP-ribosylation of signal-transducing guanine nucleotide-binding proteins by pertussis toxin. Curr Top Microbiol Immunol 175:69-96.

Glatt CE, Snyder SH (1993) Cloning and expression of an adenylyl cyclase localized to the corpus striatum. Nature 361:536-538.

Goh JW, Pennefather PS (1989) A pertussis toxin-sensitive G protein in hippocampal long-term potentiation. Science 244:980-983.

Goh JW, Pennefather PS (1990) Pertussis toxin prevents induction of hippocampal long-term potentiation in the stratum radiatum and stratum oriens inputs to CA1 neurons. Brain Res 511:345-348.

Hasselmo ME, Barkai E (1995) Cholinergic modulation of activitydependent synaptic plasticity and associative memory function in a network biophysical simulation. J Neurosci 15:6592-6604.

Hellevuo K, Yoshimura M, Kao M, Hoffman PL, Cooper DMF, Tabakoff B (1993) A novel adenylyl cyclase sequence cloned from the human erythroleukemia cell line. Biochem Biophys Res Commun 192:311-318.

Hellevuo K, Yoshimura M, Mons N, Hoffman PL, Cooper DMF, Tabakoff B (1995) The characterization of a novel human adenylyl cyclase which is present in brain and other tissues. J Biol Chem 270: 11581-11589.

Hsia JA, Moss J, Hewlett EL, Vaughan M (1984) ADP-ribosylation of adenylate cyclase by pertussis toxin: effects on inhibitory agonist binding. J Biol Chem 259:1086-1090.

Huang YY, Li XC, Kandel ER (1994) cAMP contributes to mossy fiber LTP by initiating both a covalently mediated early phase and a macromolecular synthesis-dependent late phase. Cell 79:69-79.

Huang YY, Kandel ER, Varshavsky L, Brandon EP, Qi M, Idzerda RL,
McKnight GS, Bourtchouladze R (1995) A genetic test of the effects of mutations in PKA on mossy fiber LTP and its relation to spatial and contextual learning. Cell 83:1211-1222.

Impey S, Wayman G, Wu Z, Storm DR (1994) The type I adenylyl cyclase functions as a coincidence detector for control of CREmediated transcription: synergistic regulation of transcription by $\mathrm{Ca}^{2+}$ and isoproterenol. Mol Cell Biol 14:8272-8281.

Inglese J, Luttrell LM, Iniguez-Lluhi JA, Touhara K, Koch WJ, Lefkowitz RJ (1994) Functionally active targeting domain of the betaadrenergic receptor kinase: an inhibitor of $\mathrm{G}$ beta/gamma-mediated stimulation of type II adenylyl cyclase. Proc Natl Acad Sci USA 91:3637-3641.

Ishikawa Y, Katsushika S, Chen L, Halnon NJ, Kawabe J, Homcy CJ (1992) Isolation and characterization of a novel cardiac adenylyl cyclase cDNA. J Biol Chem 267:13553-13557.

Ito I, Okada D, Sugiyama H (1988) Pertussis toxin suppresses long-term potentiation of hippocampal mossy fiber synapses. Neurosci Lett 90:181-185.

Iyengar R (1993) Molecular and functional diversity of mammalian $G_{s}$ stimulates adenylyl cyclases. FASEB J 7:768-775.

Jacobowitz O, Chen J, Premont RT, Iyengar R (1993) Stimulation of specific types of $\mathrm{G}_{\mathrm{s}}$-stimulated adenylyl cyclases by phorbol ester treatment. J Biol Chem 268:3829-3832.

Katada T, Ui M (1982) ADP-ribosylation of the specific membrane protein of C6 cells by islet-activating protein associated with modification of adenylate cyclase activity. J Biol Chem 257:7210-7216.

Katsushika S, Chen L, Kawabe J, Nilakantan R, Halnon NJ, Homcy CJ, Ishikawa Y (1992) Cloning and characterization of a sixth AC: types $\mathrm{V}$ and VI constitute a subgroup within the mammalian AC family. Proc Natl Acad Sci USA 89:8774-8778.

Koch WJ, Hawes BE, Inglese J, Luttrell LM, Lefkowitz RJ (1994) Cellular expression of the carboxyl terminus of a $G$ protein-coupled receptor kinase attenuates $\mathrm{G}$ beta/gamma-mediated signalling. J Biol Chem 269:6193-6197.

Krupinski J, Coussen F, Bakalyar HA, Tang WJ, Feinstein PG, Orth K, Slaughter C, Reed RR, Gilman AG (1989) Adenylyl cyclase amino acid sequence: possible channel- or transporter-like structure. Science 244:1558-1564.

Laemmli UK (1970) Cleavage of structural proteins during the assembly of the head of bacteriophage T4. Nature 227:680-685.

Lim C, Blume HW, Madsen JR, Saper CB (1997) Connections of the hippocampal formation in humans: I. The mossy fiber pathway. J Comp Neurol 385:325-351.

Lustig KD, Conklin BR, Herzmark P, Taussig R, Bourne HR (1993) Type II adenylyl cyclase integrates coincident signals from $G_{s}, G_{i}$, and $\mathrm{G}_{\mathrm{q}}$. J Biol Chem 268:13900-13905.

Luttrell LM, Hawes BE, Touhara K, van Biesen T, Koch WJ, Lefkowitz RJ (1995) Effect of cellular expression of pleckstrin homology domains on $\mathrm{G}_{\mathrm{i}}$-coupled receptor signalling. $\mathrm{J}$ Biol Chem 270: 12984-12989.

Mons N, Harry A, Dubourg P, Premont RT, Iyengar R, Cooper DMF (1995) Immunohistochemical localization of adenylyl cyclase in rat brain indicates a highly selective concentration at synapses. Proc Natl Acad Sci USA 92:8473-8477.

Neer EJ, Lok JM, Wolf LG (1984) Purification and properties of the inhibitory guanine nucleotide regulatory unit of brain adenylate cyclase. J Biol Chem 259:14222-14229.

Nielsen MD, Chan GC-K, Poser SW, Storm DR (1996) Differential regulation of type I and type VIII $\mathrm{Ca}^{2+}$-stimulated adenylyl cyclases by $\mathrm{G}_{\mathrm{i}}$-coupled receptors in vivo. J Biol Chem 271:33308-33316.

Olianas MC, Ingianni A, Onali P (1998) Role of G protein $\beta \gamma$ subunits in muscarinic receptor-induced stimulation and inhibition of adenylyl cyclase activity in rat olfactory bulb. J Neurochem 70:2620-2627.

Onali P, Olianas MC (1998) Identification and characterization of muscarinic receptors potentiating the stimulation of adenylyl cyclase activity by corticotropin-releasing hormone in membranes of rat frontal cortex. J Pharmacol Exp Ther 286:753-759.

Pian MS, Dobbs LG (1995) Evidence for G beta/gamma-mediated crosstalk in primary cultures of lung alveolar cells. J Biol Chem 270: 7427-7430.

Premont RT, Chen J, Ma HW, Ponnapalli M, Iyengar R (1992) Two members of a widely expressed subfamily of hormone-stimulated adenylyl cyclases. Proc Natl Acad Sci USA 89:9809-9813. 
Premont RT, Matsuoka I, Mattei M-G, Pouille Y, Defer N, Hanoune J (1996) Identification and characterization of a widely expressed form of adenylyl cyclase. J Biol Chem 271:13900-13907.

Salomon Y, Londos D, Rodbell M (1974) A highly sensitive adenylate cyclase assay. Anal Biochem 58:541-548.

Shen Y, Monsma FJ, Metcalf MA, Jose PA, Hamblin MW, Sibley DR (1993) Molecular cloning and expression of a 5-hydroxytryptamine7 serotonin receptor subtype. J Biol Chem 268:18200-18204.

Sunahara RK, Dessauer CW, Gilman AG (1996) Complexity and diversity of mammalian adenylyl cyclases. Annu Rev Pharmacol Toxicol 36:461-480.

Tang WJ, Gilman AG (1991) Type specific regulation of adenylyl cyclase by $\mathrm{G}$ protein beta/gamma subunits. Science $254: 1500-1503$.

Taussig R, Gilman AG (1995) Mammalian membrane-bound adenylyl cyclases. J Biol Chem 270:1-4.

Tsu RC, Wong YH (1996) $\mathrm{G}_{\mathrm{i}}$-mediated stimulation of type II adenylyl cyclase is augmented by $\mathrm{G}_{\mathrm{q}}$-coupled receptor activation and phorbol ester treatment. J Neurosci 16:1317-1323.

Villacres EC, Wong ST, Chavkin C, Storm DR (1998) Type I adenylyl cyclase mutant mice have impaired mossy fiber long-term potentiation. J Neurosci 18:3186-3194.

Wayman GA, Impey S, Wu Z, Kindsvogel W, Prichard L, Storm DR (1994) Synergistic activation of the type I adenylyl cyclase by $\mathrm{Ca}^{2+}$ and $\mathrm{G}_{\mathrm{s}}$-coupled receptors in vivo. J Biol Chem 269:25400-25405.

Wayman GA, Hinds TR, Storm DR (1995) Hormone stimulation of type III adenylyl cyclase causes $\mathrm{Ca}^{2+}$ oscillations in HEK-293 cells. J Biol Chem 270:24108-24115.

Weisskopf MG, Castillo PE, Zalutsky RA, Nicoll RA (1994) Mediation of hippocampal mossy fiber long-term potentiation by cyclic AMP Science 265:1878-1882.

West RE, Moss J, Vaughan M, Liu T, Liu T-Y (1985) Pertussis toxincatalyzed ADP-ribosylation of transducin. J Biol Chem 260: $14428-14430$

Williams SH, Johnston D (1996) Actions of endogenous opioids on NMDA receptor-independent long-term potentiation in area CA3 of the hippocampus. J Neurosci 16:3652-3660.

Wong YH, Federman A, Pace AM, Zachary I, Evans T, Pouyssegur J, Bourne HR (1991) Mutant alpha subunits of $G_{i 2}$ inhibit cyclic AMP accumulation. Nature 351:63-65.

Wu ZL, Thomas SA, Villacres EC, Xia Z, Simmons ML, Chavkin C, Palmiter RD, Storm DR (1995) Altered behavior and long-term potentiation in type I adenylyl cyclase mutant mice. Proc Natl Acad Sci USA 92:220-224.

Xia ZG, Refsdal CD, Merchant KM, Dorsa DM, Storm DR (1991) Distribution of mRNA for the calmodulin-sensitive adenylate cyclase in rat brain: expression in areas associated with learning and memory. Neuron 6:431-443.

Xia Z, Choi EJ, Blazynski C, Storm DR (1995) Do the calmodulin stimulated adenylyl cyclases play a role in neuroplasticity? Behav Brain Sci 18:429-440.

Yoshimura M, Cooper DM (1992) Cloning and expression of a $\mathrm{Ca}^{2+}$ inhibitable adenylyl cyclase from NCB-20 cells. Proc Natl Acad Sci USA 89:6716-6720.

Zimmermann G, Taussig R (1996) Protein kinase C alters the responsiveness of adenylyl cyclases to $\mathrm{G}$ protein alpha and beta/gamma subunits. J Biol Chem 271:27161-27166. 